\title{
Transformations in the Family System after the Birth of a Child with Disability
}

\author{
Julia Sursis Nobre Ferro Bucher-Maluschke ${ }^{1}$ \\ Rosilda Alves de Oliveira ${ }^{1}$ \\ Jonas Carvalho e Silva ${ }^{2}$ \\ Carlos Manoel Lopes Rodrigues ${ }^{1}$
}

\begin{abstract}
The arrival of a child with disability causes changes in the family structure and dynamics. The objective of this study was to identify the parents' reactions after the transmission of the diagnosis of disability of their child and its repercussions on the family. A semi-structured interview was carried out with three couples with a child, which identified the profile and the transformations in the family system. The data analysis, with the aid of the IRaMuTeQ program (lexographic analysis and Descending Hierarchical Classification), resulted in the classs/categories: birth and mourning, pregnancy and care, routine and overload, spirituality and intrafamily relationships. The transformations in the family dynamics provoked feelings of mourning, overload of the couples, the need for a support network and, in some cases, the connection with spirituality. In conclusion, there is a need for interprofessional and intersectoral research in view of the communication of the diagnosis and the changes throughout the life of the family.
\end{abstract}

Keywords: family, people with disabilities, diagnosis

\section{Transformações no Sistema Familiar após o Nascimento de um Filho com Deficiência}

\begin{abstract}
Resumo: A chegada de uma criança com deficiência provoca alterações na estrutura e dinâmica familiar. O objetivo deste estudo foi identificar as reações dos pais após a transmissão do diagnóstico de deficiência do filho e as suas repercussões na família. Foi realizada uma entrevista semiestruturada com três casais com um filho, que identificou o perfil e as transformações no sistema familiar. A análise dos dados, com auxílio do programa Iramuteq (análise lexográfica e Classificação Hierárquica Descendente), resultou nas classes/ categorias: nascimento e luto, gravidez e cuidados, rotina e sobrecarga, espiritualidade e relações intrafamiliares. As transformações na dinâmica familiar provocaram sentimentos de luto, sobrecarga dos casais, a necessidade de uma rede de apoio e, em alguns casos, de ligação com a espiritualidade. Conclui-se que há a necessidade da pesquisa interprofissional e intersetorial face à transmissão do diagnóstico e às transformações ao longo da vida da família.
\end{abstract}

Palavras-chave: família, pessoas com deficiência, diagnóstico

\section{Transformaciones en el Sistema Familiar tras el Nacimiento de un Hijo con Discapacidad}

\begin{abstract}
Resumen: La llegada de un hijo con discapacidad provoca cambios en la estructura y la dinámica familiar. El objetivo de este estudio fue identificar las reacciones de los padres tras el diagnóstico de discapacidad de su hijo y las repercusiones en la familia. Se realizó una entrevista semiestructurada a tres parejas con un hijo para identificar el perfil y las transformaciones en el sistema familiar. El análisis de los datos, con ayuda del programa Iramuteq (análisis lexicográfico y Clasificación jerárquica descendente), dio lugar a las siguientes clases/categorías: nacimiento y duelo, embarazo y cuidados, rutina y sobrecarga, espiritualidad y relaciones intrafamiliares. Las transformaciones en la dinámica familiar provocaron sentimientos de duelo, la sobrecarga de las parejas, la necesidad de una red de apoyo y, en algunos casos, la conexión con la espiritualidad. Se concluye que es necesaria la investigación interprofesional e intersectorial de cara a la transmisión del diagnóstico y a las transformaciones a lo largo de la vida de la familia.
\end{abstract}

Palabras clave: familia, personas con discapacidad, diagnóstico

${ }^{1}$ Centro Universitário de Brasilia, Brasilia-DF, Brazil

${ }^{2}$ Tecnische Universität Dortmund, Germany

Support: Financial support from CNPq. - process No. 311386/2018

Correspondence address: Júlia Sursis Nobre Ferro Bucher-Maluschke. SHCGN 716, Bloco T, Casa 21, Asa Norte, Brasília-DF, Brazil. CEP 70.770-750. E-mail: psibucher@gmail.com
The family's origin is as old as the rise of civilization, having emerged as a natural phenomenon, given the need for human beings to remain affectionately linked to one another. Like any historical phenomenon, the concept of family has undergone several modifications over time (Bucher-Maluschke, 2007; Fiamenghi Junior \& Messa, 2007). Cerqueira-Silva and 
Dessen (2018) indicate that the person's socialization process begins in the family, where union, acceptance, respect, appreciation of family members are fostered, as well as enhance emotional well-being and its development.

In this perspective, most family models in psychology and sociology studies use the family classification by Kaslow (2001), which are: nuclear family, including two generations with biological children; extended families, including three or four generations; adoptive families, which can be biethnic or multiethnic; couples, the one in which man and woman are linked via marriage, but neither conceive nor adopt children; single-parent families, headed by a father or mother; homoaffective (homoparental) couples, with or without children; reconstituted families after divorce; several people living together, without legal ties, but with a strong mutual commitment.

Bucher-Maluschke and Parreira (2017) state that based on a systemic perspective, the family should be seen as a system that supports a hierarchical structure of its members, constituted in subsystems, i.e., a system within other systems with rules that regulate the relationships between family members. The authors present the various subsystems present in the family: the marital subsystem, composed of husband and wife; the filial subsystem, which happens with the birth of the first child followed by the others; parental subsystem, whose function is the education, socialization, and protection of children; and the sibling subsystem, composed of siblings.

Thus, the parental subsystem is formed with the first child's birth; the couple is now constituted as father and/ or mother. This new state brings with it profound changes in their individual dynamics and marital relationship. According to Harvey (2020) and Zornig (2010), parenthood is a term used in French psychoanalytic literature from the 1960s onwards, which marks the construction of the exercise of the relationship between parents and children. However, parenthood is not only an influence of parents on their children, but it constituted a set of interrelated interactions that start from the child's birth (Bucher-Maluschke, 2007; Fiamenghi Junior, \& Messa, 2007; Marquis, McGrail, \& Hayes, 2020; Namkung, Mitra, \& Nicholson, 2019).

Waiting during pregnancy involves preparing the couple for the birth of a child. From the outset, the idealized existence of this new member appears, which is desired to be born healthy (Bucher-Maluschke, 2007). Parents experience this process with much expectation: the child is intensely idealized by desires, dreams, and (re) encounters of their history in that child. Therefore, there is a connection, a project with and for the child, to which perfection is attributed (Harvey, 2020).

When parents receive the news that their child has a disability, there is a feeling of loss of the idealized and desired child. The experience of mourning the idealized child is required so that the actual child can be welcomed and accepted within the family (Harvey, 2020). The feelings that emerge at this time are diverse, such as fear, anxiety, shame, and guilt (I.G. Oliveira \& Polleto, 2015; Silva \& Ramos, 2014). Difficulties may arise for parents to deal with this real child, considering their fragility, feeling frustrated in their intimacy and society (Marquis et al., 2020; Syed, Awan, \& Syeda, 2020).

Literature reviews, developed by Fiamenghi Junior and Messa (2007) and later by Mandleco and Webb (2015), reveal that the influence of family relationships is evident in families with disabled children, as it is an unexpected experience of change of parents' plans and expectations. For Mandleco and Webb (2015), the family context is where the processes of socialization, sharing, and inclusion of people with disabilities begin. The authors also highlight the significance of social support networks in assistance and support to the family and social inclusion of individuals with disabilities.

In this sense, Silva and Ramos (2014) associated the reactions and feelings of parents when faced with the news of their child's disability with the unpreparedness of health care professionals at the time of diagnosis. How the news is given to parents can significantly influence their reactions, as the diagnosis is often confused with the omission of information or minimization of the problem. For the authors, these factors can influence the acceptance of this child by the family and form a bond.

Also, concerning the parents' feelings when they receive confirmation of the child's disability diagnosis, they emphasize that the feeling of abandonment experienced by the parents can be reduced if more appropriate attitudes are used when informing the child's diagnosis. Therefore, the family's role and professional support networks in accepting the child and the possibility of these parents giving new meanings to their lives are reinforced (Bucher-Maluschke \& Parreira, 2017).

Note that the United Nations Committee on the Rights of the Child encourages and emphasizes carrying out awareness campaigns. Such campaigns, aimed at government officials, civil society, and families, fight stigmatization and prejudice against children with disabilities and promote a positive image (United Nations Convention on the Rights of the Child, 2015). However, there is a lack of studies in the relationship between healthcare professionals and the family system regarding communicating disabilities diagnosis after birth. Even though intersectoral and interprofessional action policies have advanced considering humanizing communication procedures, changes throughout the family's life still require further studies (Bucher-Maluschke \& Parreira, 2017).

Thus, the question concerning the family system is: What are the main changes caused by the birth of a child with a disability? This study aimed to identify parents' reactions after communicating the child's disability diagnosis and its repercussions on the family. This revelation, still centered on the doctor's figure, is suggested to provoke changes throughout family development, influencing the person's acceptance of a disability.

\section{Method}

This qualitative study adopted the strategy of multiple cases, defined by Yin (2004). The investigator deeply explores 
a program, an event, an activity, and a process with one or more individuals. This type of study was chosen in order to identify a problem, to analyze the evidence, to develop logical arguments, to evaluate, and to propose solutions.

\section{Participants}

Three couples participated in this study (father and mother), chosen among those who had one or more children with a disability, named in this manuscript family 1 (F.1), family 2 (F.2), and family 3 (F.3). Family nuclei that lived in the same household in the Federal District, Brazil, and was assisted by public care for people with disabilities were included. As a result, families who did not contact their disabled child, homeless people, institutionalized people, or people under the supervision of the State were excluded.

\section{Instruments}

Semi-structured interview. The script consisted of two parts. The first contained seven closed questions to identify the child's diagnosis, family income, religion, and family members, which were answered by the mothers. In the second, there were seven more open questions about the history of family life until pregnancy, the moment of diagnosis, birth, and the main changes that occurred with the child's arrival with a disability.

\section{Procedure}

Data collection. The research was conducted in the Federal District of Brazil. The administrative regions are served by basic sanitation, extensive commerce, and free health care services are provided, such as health units and emergency care units.

The authors collected information from May to September of 2019. The visits took place in the families' households, presenting the research objectives, the importance of their participation, the guarantee of anonymity, the confidentiality of information, and the possibility of quitting at any stage of the research. Two interviews were carried out with each couple. Each meeting lasted approximately two hours, and the first was previously scheduled by telephone call.

The first part of the interview script was carried out after signing the free consent form, followed by open questions. At this point, authorization was requested to record the interviews, which the families granted. Although there was a previous script, families were allowed to answer the questions in the best way. Only when a question was not addressed the interviewer would introduce the question to understand the facts better.

Data analysis. The interviews containing the closed questions were systematized in an information board to characterize the families' profiles. After being derecorded and transcribed, the answers to the open questions were submitted to lexical analysis using the Interface de $R$ pour les Analyses Multidimensionnelles de Textes et de Questionnaires (IRaMuTeQ) software, version 0.7 alpha 2 (Ratinaud, 2009). The meaning classes were generated from applying the Descending Hierarchical Classification method - DHC (Reinert, 1990). The results indicated the lexical analysis of the classes.

The deepening of the meanings of the textual segments were performed by a deductive analysis based on the six steps proposed by Creswell (2013): first, organization of the collected material, transcription of interviews, and preparation of information sources; second, reading of material, capture of general information, reflection on the general idea conveyed; third, data codification; fourth, description of the encoding process and detailed presentation of information; fifth, description of the themes elaborated within the work; sixth, data interpretation. Qualitative analysis resulted in the interpretation of classes grouped into the following categories: birth and mourning, pregnancy and care, routine and overload, spirituality, and intrafamily relationships.

\section{Ethical Considerations}

The cases presented in this study are part of the research "Family Structure and Dynamics of a Child with Intellectual and/or Multiple Disabilities and Repercussions on Siblinghood," submitted and approved by the Research Ethics Committee with Human Beings of the Centro Universitário de Brasília, under the CAAE registration 00259018.0.0000.0023 and Opinion No. 3,023,674, following the regulations of Resolution No. 466/12 of the National Health Council of the Brazilian Ministry of Health, which deals with ethics in research with human beings as contained in the free consent form.

\section{Results}

\section{Characterization of participants}

The first family (F.1) residing in the administrative region of Recanto das Emas is composed of a father, mother, a 16-year-old disabled son, and a 13-year-old daughter. The mother is 46 years old, carries out exclusively household chores and the care of the family, and it is her first marriage. The father is a member of the Military Service reserve, is 57 years old, in his second marriage, and has two daughters from his first marriage. All members identify themselves as Catholics. Family income is around four minimum wages. The son was diagnosed with Myelomeningocele in the fifth month of pregnancy. This pathology occurs due to an embryonic malformation of the central nervous system, which can occur in the first four weeks of pregnancy due to failure in closing the neural tube, causing different degrees of functional alteration of the spinal cord (Ortiz-Quiroga, Ariza-Araújo, Pachajoa, \& Ramirez-Botero, 2018).

The second family (F.2), residing in the administrative region of Paranoá, consists of the mother, the father, both 64 years old and married for 42 years, five children 
(three men and two women). The youngest one is disabled, 24 years old. In this family, the father is retired, and the mother is a housewife. Both call themselves Catholics. Family income is around three minimum wages. The diagnosis of cerebral palsy was only revealed two months after birth. According to Carcreff et al. (2020), a cerebral palsy is a group of permanent disorders in the development of movement and posture. It is caused by a non-progressive disorder present in the fetal or infant brain development, leading to limitations in the individual's functionality profile.

The third family (F.3), living in the administrative region of Guará, comprises a father, mother, and a 4-yearold daughter, whose diagnosis of Down syndrome was communicated at her birth. The mother is 43 years old, a federal public servant, and in her first marriage. As for the father, he owns a bar in the city where he lives; he is 47 years old and is in his third marriage. He has four children: a daughter from his first marriage, two sons from his second, and a daughter from the current marriage. The family has no religious affiliation, and the income is around five minimum wages. Down syndrome (DS) or trisomy 21 is a condition caused by a chromosomal alteration (chromosomopathy), which is the most common alteration in humans, and considered the leading cause of intellectual disability in the population (Marquis et al., 2020).

\section{Lexical Analysis}

The general corpus consisted of three texts, separated into 369 clippings of segments of text (ST), using 314 STs (85.09\%) of the total. A total of 13,108 occurrences were identified (words, forms, or vocables), with 2099 distinct words and 573 hapaxes, i.e., words with a single occurrence $(4.37 \%$ of the occurrences). The analyzed content was categorized into five Classes: Class 1, with 90 ST (28.66\%); Class 2, with 59 ST (18.79\%); Class 3, with 50 ST (15.92\%); Class 4, with 51 ST (16.24\%); and Class 5, with 64 ST $(20.38 \%)$.

The five classes formed by the Descending Hierarchical Classification (DHC) are divided into two branches. The classes were grouped into a first set consisting of Class 3 and Class 2. The second set includes Class 5 and Class 1. Classes 4 and 1 form a subset next to Class 5 (Figure 1).

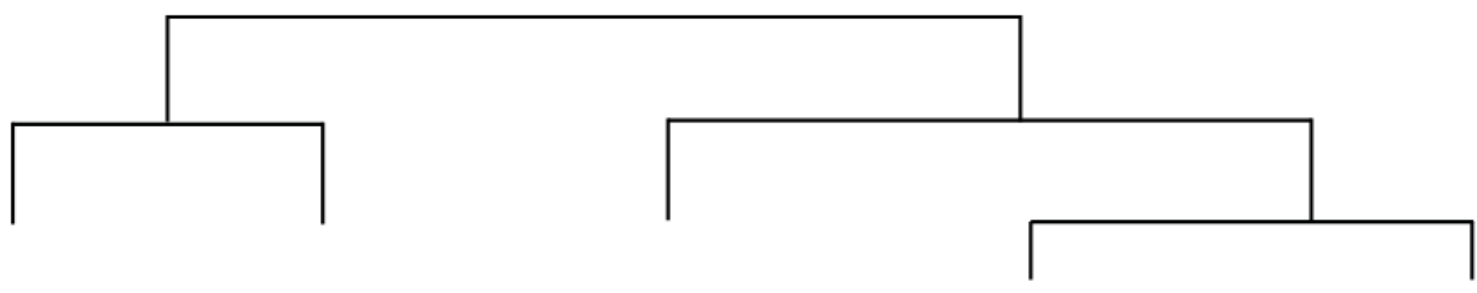

\begin{tabular}{|c|c|c|c|c|c|c|c|c|c|c|c|c|c|c|}
\hline \multicolumn{3}{|c|}{$\begin{array}{c}\text { Class } 3 \\
\text { Birth and mourning } \\
50 \text { ST }(15.92 \%) \\
\text { Predominance of } \\
\text { evocations of Family } 3 \\
\left(23 \mathrm{ST} ; \mathrm{c}^{2}=5.22\right)\end{array}$} & \multicolumn{3}{|c|}{$\begin{array}{c}\text { Class } 2 \\
\text { Pregnancy and care. } \\
\text { 59 ST (18.79\%) } \\
\text { There was no } \\
\text { predominance of } \\
\text { evocations }\end{array}$} & \multicolumn{3}{|c|}{$\begin{array}{c}\text { Class } 5 \\
\text { Routine and overload } \\
64 \text { ST }(20.38 \%) \\
\text { There was no } \\
\text { predominance of } \\
\text { evocations }\end{array}$} & \multicolumn{3}{|c|}{$\begin{array}{c}\text { Class 4 } \\
\text { Spirituality } \\
\text { 51 ST }(16.24 \%) \\
\\
\text { Predominance of } \\
\text { evocations of Family } 1 \\
\left(32 \mathrm{ST} ; \mathrm{c}^{2}=2.86\right)\end{array}$} & \multicolumn{3}{|c|}{$\begin{array}{c}\text { Class 1 } \\
\text { Intrafamily relationship } \\
90 \mathrm{ST}(28.66 \%) \\
\text { Predominance of } \\
\text { evocations of Family } 2 \\
\left(19 \mathrm{ST} ; \mathrm{c}^{2}=2.54\right)\end{array}$} \\
\hline Form & $f$ & $\chi^{2}$ & Form & $f$ & $\chi^{2}$ & Form & $f$ & $\chi^{2}$ & Form & $f$ & $\chi^{2}$ & Form & $f$ & $\chi^{2}$ \\
\hline baby & 22 & 94.83 & pregnancy & 21 & 60.21 & tennis & 8 & 32.07 & god & 21 & 91.67 & father & 16 & 33.87 \\
\hline doctor & 23 & 37.3 & childbirth & 9 & 40.05 & therapy & 8 & 32.07 & person & 17 & 74.23 & mother & 24 & 32.78 \\
\hline head & 6 & 32.3 & month & 14 & 33.81 & consultation & 10 & 26.72 & independent & 5 & 26.2 & son & 47 & 26.89 \\
\hline problem & 10 & 30.3 & nausea & 7 & 30.94 & $\begin{array}{l}\text { physical } \\
\text { therapy }\end{array}$ & 6 & 23.89 & grace & 5 & 26.2 & boy & 10 & 15.45 \\
\hline body & 5 & 26.83 & pregnant & 10 & 26.61 & past & 6 & 23.89 & limitation & 4 & 20.89 & small & 6 & 11.4 \\
\hline case & 6 & 26.05 & hospital & 12 & 23.77 & time & 13 & 21.84 & possible & 4 & 20.89 & taste & 4 & 10.08 \\
\hline healthy & 4 & 21.39 & kilo & 5 & 21.96 & nursery & 6 & 18.83 & faith & 4 & 20.89 & brother & 11 & 9.83 \\
\hline arm & 4 & 21.39 & final & 5 & 21.96 & swimming & 6 & 18.83 & future & 5 & 20.24 & church & 5 & 8.94 \\
\hline room & 4 & 21.39 & high & 6 & 21.01 & school & 12 & 18.74 & difficulty & 5 & 20.24 & jealousy & 5 & 8.94 \\
\hline scared & 4 & 21.39 & direct & 4 & 17.51 & work & 10 & 18.43 & better & 7 & 18.82 & difficult & 7 & 8.63 \\
\hline fear & 7 & 16.76 & diet & 4 & 17.51 & year & 13 & 16.73 & essay & 6 & 17.32 & people & 7 & 8.63 \\
\hline surgery & 5 & 16.48 & day & 18 & 15.49 & bedsore & 4 & 15.83 & difference & 4 & 15.18 & special & 9 & 7.57 \\
\hline perfect & 3 & 15.99 & calm & 7 & 15.02 & tired & 4 & 15.83 & big & 7 & 14.1 & people & 3 & 7.54 \\
\hline child & 10 & 12.86 & infection & 3 & 13.09 & room & 4 & 15.83 & different & 5 & 12.91 & old & 3 & 7.54 \\
\hline
\end{tabular}

Figure 1. Descending Hierarchical Classification. $\mathrm{ST}=$ Text Segment; $f=$ Frequency; $\chi^{2}=$ Chi-square. Forms identified with significance $p=0.000$. 
Class 3, called Birth and Mourning, is composed of words like baby, doctor, problem, and body. There was a predominance of evocations from Family 3 over other families ( $23 \mathrm{ST} ; \chi^{2}=5.22, p=0.000$ ). This Class is the basis for forming other classes. It emerges as the primary focus to start presenting the families' narratives about the impacts caused by the diagnosis of disability. Its content suggests a focus on the child represented by the word baby, relating the expectation that the family has with the child's well-being and the expectation of the idealized child.

Class 2 was categorized as Pregnancy and Care and consisted of words such as pregnancy, childbirth, month, nausea, and hospital. There was no predominance of evocations of one family over the others. This Class deals with mothers' difficulties during pregnancy, as content related to health status emerges. The analyses highlighted the frequencies of the words nausea, kilogram, and diet.

Class 5 was called Routine and Overload and comprises words like tennis, therapy, consultation, physical therapy, and past. There was no predominance of evocations of one family over the others. The words identified in this class mention aspects related to families' activities to provide their children's social inclusion and the care required for people with disabilities. As a result, two words appeared: work and tired, which reflect the feelings, especially of mothers, with the exhaustive routine of caring for their children.

Class 4 was called Spirituality, composed of words like god, person, independent, grace, and limitation. There was a predominance of evocations from Family 1 over other families (32 ST; $\chi^{2}=2.86, p=0.000$ ). In this class, the word god emerged with a more significant presence. The word grace is also linked to god, which led us to infer that the theme of spirituality can arise as a strategy for acceptance and overcoming under challenging times a family goes through. Spirituality is understood here as belief in a superior being.

Class 1 was categorized as Intrafamily Relationship, composed of words like father, mother, son, boy, and small. There was a predominance of evocations from Family 2 over the other families (19ST; $\left.\mathrm{x}^{2}=2.54, p=0.000\right)$. The highlighted words present evocations that refer to the relationships that occur in the intrafamily system, i.e., between the family subsystems with a member with a disability. As mentioned before, the arrival of a person with a disability in the family affects the entire family system.

\section{Discussion}

\section{Birth and Mourning}

The focus of analysis in this category is exploring the birth of a child with a disability, conflicts arising in parents, and their consequences. When they receive the news that their child has a disability, parents usually have several reactions similar to a grieving process, such as shock, sadness, anger, and anxiety (Marquis et al., 2020). Doubts, uncertainties, and especially the fear of not knowing how to deal with this new reality will lead to significant changes in the family environment (I.G. Oliveira \& Polleto, 2015; Silva \& Ramos, 2014; Syed et al., 2020).

In this sense, Harvey (2020) explored how disability evokes family estrangement of maternal love for the child. Das Unheimlich is a German term from psychoanalysis, which refers to a psychological experience of familiarity, and at the same time, frightening, arousing a sense of uncertainty, dread, and horror. The author argues that the mother's sense of self and feelings never stabilize, given the child's disability, because her subjectivity is continually interrupted by external interference. Although maternal love is more explicitly expressed than hate, parental discomfort can present the unconscious presence of a powerful and complex ambivalence.

At this time, psychological support is essential to mitigate the negative effect that parents experience. In the study, the word doctor was observed with the secondhighest frequency. It is noteworthy due to the parents' narrative about interprofessional support and intersectoral communication policies in health. When the diagnosis is informed, this narrative indicates the absence of guidance and follow-up throughout the child's life. In this regard, the feeling of abandonment experienced by parents, which could be reduced if more appropriate attitudes were used when informing their parents of the child's diagnosis (Bucher-Maluschke \& Parreira, 2017).

The text segments that captured excerpts were: "When I received this news, I was very scared, very sad. I think the doctor didn't know how to talk; he didn't know how to convey the problem to us. We suffered a lot the day we found out, but then we dealt with it" (F.1). "The doctor said: Your child will not walk anymore, he was born with microcephaly, your child's head will not grow. I just cried" (F.2). "The doctors made us apprehensive as if it were something worse than it is; they end up making us more worried" (F.3).

This is a very delicate period for parents and healthcare professionals in charge of informing about the child's disability. In this context, more preparation of health care professionals is necessary concerning the communication of the diagnosis and the provision of integrated care. Especially at communication, support should be offered to the family, with the necessary support and clarification on alternative care for their child.

\section{Pregnancy and Care}

This category aims to explore parents' experiences about care activities in the prenatal period, potentially influencing the health and well-being of the couple and their children. Pregnancy is a period in a woman's life that requires extra care, considering that at this moment, the mother carries another being in her womb. At this stage, the elaboration of internal models for care begins, which will develop from the perception of the new child, self, and others, and the formation of care goals (McKechnie, Rogstad, Martin, \& Pridham, 2018; Namkung et al., 2019). Quality of care 
for these goals and partner expectations can occur during pregnancy (Bowlby, 1990).

The text segments that captured excerpts were: "I gained much weight; at the end of my pregnancy, I had to go on a diet because I gained 22 kilos. When I discovered my pregnancy, it was already ongoing for 03 and a half months. I didn't feel nauseous; I didn't feel anything" (F.1). "I felt much pain, much contraction, and I worked a lot in a family home, I worked all day. I attended prenatal care at the Health Unit; I felt many allergies during pregnancy, I was very allergic" (F.2). "The pregnancy was very complicated because I had a lot of nausea, everything I ate I vomited, and I also lost much weight. We found out when I got sick" (F.3).

In this perspective, care was related to the interests of the parents during the physical and emotional transformations during the gestational period to verify the parental processes that were best suited to prenatal planning. The results suggest that, for parents, social support and professional follow-up are considered to be of great importance. Mothers, in particular, wanted to get information and advice, have their questions answered, reduce anxiety, and share their experiences with other pregnant couples.

The care needed during pregnancy, such as nutrition, can influence the baby's health. Hence, parents must prioritize healthcare in general and food in particular. For McKechnie et al. (2018), couples engaged in mutual support to achieve care goals and to share information during pregnancy contribute to the feeling of normality up to the first three years after birth. The healthcare team must inform these guidelines and develop a welcoming and empathetic relationship with the family (BucherMaluschke \& Parreira, 2017).

\section{Routine and Overload}

This category examined the relationship of emotional experiences of parents of children with disabilities orchestrated by daily routine activities in the family system. Overload, in this context, refers to tiredness and the demands of care. Although the mothers reported the fathers' help, most tasks were considered their attribution, overloading them.

In a study on the care services provided to families with special needs, Cerqueira-Silva and Dessen (2018) corroborate the findings of this research. Mothers have greater responsibilities in both the division of domestic tasks and caring for the children, while fathers play a supporting role, even when they carry out household chores. Regarding the supporting role of men, a process of transformation in gender relations can be observed in the relationship between spouses. Both can be providers and, at the same time, caregivers during daily routine activities.

The segments of texts in which these words appear more strongly are: "There is no time to take care of myself; it makes me very tired, overloaded with so many things to do. With his birth, I, who was already nauseous and boring, became even more boring cleaning and taking care of him" (F.1). "My routine is very tiring; I feel very, very tired. I'm constantly overloaded with a thousand things to do; my husband doesn't help me much because he doesn't believe that physical therapy is good" (F.3).

It was all day out, leaving in the morning and arriving at night. Doctors scheduled many appointments, eye exams, and I still needed to take care of the young children, going to school meetings. There were so many things that I always felt tired (F.2).

Although it is possible to verify changes regarding fathers' cooperation in household chores, mothers continue to bear most of the tasks and care as if they were the main ones responsible for this care (Harvey, 2020; Namkung et al., 2019). Faced with the exhaustive demand, they isolate themselves from society and have their coexistence cycle restricted to the family environment. Furthermore, Syed et al. (2020) assessed the overload of parents caring for children with hearing and intellectual disabilities in Pakistan. The results showed higher scores for stress, anxiety, and depression in mothers. The marital status of caregivers also significantly influenced the levels of load and stress.

The couples in this study reported investing in the future of their disabled child, taking them to activities that promote development and health. Thus, there are many visits to physical therapy sessions and consultations. In the case of F.1, the parents sought to invest in the sport, and today, the disabled son, aged 16, plays tennis in a wheelchair. F.3 mother continued to work after the birth of her daughter, increasing her overload.

Several studies point to the need for a support network for families of people with disabilities, both informal, which includes family members, friends, neighbors, colleagues, and social groups, and a formal support network, which includes professionals and institutions of education, healthcare, and leisure (Bucher-Maluschke \& Parreira, 2017; Cerqueira-Silva \& Dessen, 2018; Mandleco \& Webb, 2015; Marquis et al., 2020). Cerqueira-Silva and Dessen (2018) understand that promoting a network of services to families of children with disabilities should prioritize all government spheres. Thus, it is essential to develop and strengthen intersectoral policies more directed towards welcoming and supporting families and especially mothers, based on the diagnosis of disability, since most public care services revolve around the child.

\section{Spirituality}

This category explored the role of spirituality in the experiences of families with a child with a disability. Concerning the parents' reactions to the child's disability diagnosis, I.G. Oliveira and Polleto (2015) state that some seek spirituality to understand punishment, cure, comfort, or compensation. Others may cancel out, become frustrated or depressed, adjusting to the acceptance of the disability condition. 
The following excerpts represent the speeches that emerged in the text segments: "God knows all things. At that time God already wanted to prepare me for what I was going to live today, so I accepted. Of course it was a shock, but I tried to accept it as best I could" (F.1). "The doctor said I would have hard work for the rest of my life. He said: As long as you live and he lives, there will be a lot of work. Go live for him. I thought like this: God is great, God will help me" (F.2). "God chooses no one to have a disabled child. People try to comfort you by saying that, but I don't believe in it" (F.3).

In the text segments above, Families 1 and 2 sought answers and a source of overcoming in God's figure as a way to understand the situation, as we saw in the speech of Family 1. They see the child's disability as a mission from a superior being to which they would have to conform and accept. Spirituality seems to have provided both parents with meaning, inner strength, peace, and hope. Many people experienced self-transformation through living with disabilities, becoming more mature and compassionate parents.

However, spirituality is not always understood as a source of support. Family 3 did not attribute to any superior being the fact of their daughter's disability. They believed that "God chooses no one to have a disabled child." This data, associated with the information obtained about the child's age with a disability, indicates that the more extended experience with the child's disability develops acceptance of this situation justified by spiritual beliefs. Therefore, the child's disability is not always considered by the parents as a gift, a present from God, despite in other studies, spirituality and belief in a superior being appeared as factors that gave meaning and strength to face the problem (Bucher-Maluschke \& Parreira, 2017; I.G. Oliveira \& Polleto, 2015).

\section{Intrafamily Relationship}

This category explored the quality of parent-child and sibling relationships to understand the effects of disability on the family and the interactions between the relational structures of the family environment. The importance of informal support networks was evident. Although not directly linked to the family, they can be a source of help, as in Family 2, where they report that the neighbor helped care for the other small children.

The most representative text segments in this category were: "they used to fight a lot; today it has improved a lot, but when they were little they used to fight a lot. For whatever reason they fought, he was more teasing, more jealous, he was very jealous of his sister and father" (F.1). "She is jealous; when I am with my husband, she is jealous. She is against, if I comb her hair, she throws a tantrum and wants her father, but if it's her father, she wants her mother" (F.3).

These segments bring us the conflicts that can arise in the sibling subsystem, with fights and jealousy of both siblings and parents. In other excerpts, families refer to the support they received from other children and from people who are not directly linked to the family in caring for the disabled, such as: "She helped a lot and still helps today" (F.1). "I always took care of him alone. A neighbor helped me, she was very good, but she passed away. She took my boys to school, brought them, helped a lot. My other children, when they were little, took him outside when they went to play" (F.2). "My daughter was worried. She was very worried; she always gave us help and support" (F.1).

These excerpts allow us to infer the changes that occurred in the family dynamics with the birth of a person with a disability, demanding parents' dedication and siblings' collaboration. The need for support networks for families with disabled children was the object of study by authors such as Bucher-Maluschke and Parreira (2017), Cerqueira-Silva and Dessen (2018) and Mandleco and Webb (2015). They highlight the importance of intra and extra-family bonds to promote a better quality of life and well-being.

In conclusion, this study identified how parents react after being informed of the child's disability diagnosis and its repercussions on the family system. The research results contributed to reflection on the need for integration between professionals. It is based on diagnosing a disability in a child and the importance of intersectoral and interprofessional initiatives to develop the child and family.

The use of the Iramuteq software gave visibility to the most expressive narratives of the fathers and mothers, regarding the child's diagnosis and its repercussions throughout the family's life, especially in the organization of the family routine. The text excerpts related to the fathers were noted to appear predominantly in the category "birth and mourning," while the mothers' narratives predominated in the other categories. This limitation leads to the need to deepen the parents' narratives in other classes where their speech excerpts were not significant.

The results show how the initial moments of knowledge about a child's disability can become difficult for the family. At the time of diagnosis, the doctor's role was emphasized, and the overload of tasks that the new situation entails. The theme of spirituality also emerged in the families' speeches. In two of them, as a source of support and the child's disability as a mission. In another, as disbelief that the disability could be a divine plan or predestination. Finally, the need to establish quality intrafamily and extra-family relationships to assist in caring for people with disabilities was highlighted.

The recommendation for future studies on how diagnoses of a child's disability are informed is to deepen parents' roles in their participation in care, division of tasks, from the organization of routines to avoid the overload of any of them. Concerning intrafamily relationships, the recommendation is to study the communication between parents and children with or without disabilities and integrating spirituality as a possible resource based on the family's beliefs. 


\section{References}

Bowlby, J. (1990). Apego e perda: Vol. 1. Apego: A natureza do vínculo [Attachment and loss: Vol. 1. Attachment: The nature of the bond] (A. Cabral, Trans.). São Paulo, SP: Martins Fontes.

Bucher-Maluschke, J. S. N.F. (2007). Lei, transgressões, famílias e instituições: Elementos para uma reflexão sistêmica [Law, transgressions, families and intitutions: Elements for a systemic reflection]. Psicologia: Teoria e Pesquisa, 23(Spe), 83-87. doi:10.1590/S0102-37722007000500016

Bucher-Maluschke, J. S. N. F., \& Parreira, C. M. S. F. (2017). Família e deficiência no contexto contemporâneo [Family and disability in the contemporary context]. In E. M. Bernardi, E. Fernandes Neto, \& J. R. Pilger (Orgs.), Documento norteador: Autogestão, autodefensoria e família: Orientações para o trabalho com as famílias no contexto da Rede Apae [Guiding document: Selfmanagement, self-defense and family: Guidelines for working with families in the context of the Apae Network] (pp. 20-31). Brasília, DF: APAE Brasil. Retrieved from https://media.apaebrasil.org.br/DOCUMENTONORTEADOR-FAMILIA-FINAL-3.pdf

Carcreff, L., Gerber, C. N., Paraschiv-Ionescu, A., De Coulon, G., Newman, C. J., Aminian, K., \& Armand, S. (2020). Comparison of gait characteristics between clinical and daily life settings in children with cerebral palsy. Scientific Reports, 10(1), 2091. doi:10.1038/ s41598-020-59002-6

Cerqueira-Silva, S., \& Dessen, M. A. (2018). Programas de Educação Familiar para famílias de crianças com deficiência: Uma proposta promissora [Family Education Programs for families of children with disabilities: A promising proposal]. Contextos Clínicos, 11(1), 59-71. doi:10.4013/ctc.2018.111.05

Creswell, J. W. (2013). Qualitative inquiry research design: Choosing among five approaches (4th ed.). New York, NY: SAGE.

Fiamenghi Junior, G. A., \& Messa, A. A. (2007). Pais, filhos e deficiência: Estudos sobre as relações familiares [Parents of children and disability: Studies on family relationships]. Psicologia: Ciência e Profissão, 27(2), 236-245. doi:10.1590/s1414-98932007000200006

Harvey, C. (2020). The uncanny effect of disability: Uncomfortable maternal love for a disabled child. Contemporary Psychoanalysis, 56(1), 1-28. doi:10.1080/ 00107530.2020.1717218

Kaslow, F. W. (2001). Families and family psychology at the millennium: Intersecting crossroads. American Psychologist, 56(1), 37-46. doi:10.1037/0003-066X.56.1.37

Mandleco, B., \& Webb, A. E. M. (2015). Sibling perceptions of living with a young person with Down syndrome or autism spectrum disorder: An integrated review. Journal for Specialists in Pediatric Nursing, 20(3), 138-156. doi:10.1111/jspn.12117

Marquis, S. M., McGrail, K., \& Hayes, M. V. (2020). Mental health outcomes among parents of a child who has a developmental disability: Comparing different types of developmental disability. Disability and Health Journal, 13(2), 100874. doi:10.1016/j.dhjo.2019.100874
McKechnie, A. C., Rogstad, J., Martin, K. M., \& Pridham, K. F. (2018). An exploration of co-parenting in the context of caring for a child prenatally diagnosed and born with a complex health condition. Journal of Advanced Nursing, 74(2), 350-363. doi:10.1111/jan.13415

Namkung, E. H., Mitra, M., \& Nicholson, J. (2019). Do disability, parenthood, and gender matter for health disparities?: A US population-based study. Disability and Health Journal, 12(4), 594-601. doi:10.1016/ j.dhjo.2019.06.001

Oliveira, I. G., \& Polleto, M. (2015). Vivências emocionais de mães e pais de filhos com deficiência [Emotional experiences of mothers and fathers of children with disabilities]. Revista da SPAGESP, 16(2), 102-119. Retrieved from http://pepsic.bvsalud.org/scielo.php? script=sci arttext\&pid=S1677-29702015000200009

Ortiz-Quiroga, D., Ariza-Araújo, Y., Pachajoa, H., \& Ramirez-Botero, A. F. (2018). Intimidación escolar en niños $\mathrm{y}$ adolescentes con discapacidad como resultado de mielomeningocele [School bullying in children and adolescents with disabilities as a result of myelomeningocele]. Rehabilitación, 52(2), 93-99. doi:10.1016/j.rh.2017.11.004

Ratinaud, P. (2009). IRAMUTEQ: Interface de $R$ pour les analyses multidimensionnelles de textes et de questionnaires [IRAMUTEQ: $\mathrm{R}$ interface for multidimensional analysis of texrts and questionnaires]. Retrieved from http://www.iramuteq.org

Reinert, M. (1990). Alceste une méthodologie d'analyse des données textuelles et une application: Aurelia De Gerard De Nerval [Alceste a methodology for analyzing textual data and an application: Aurelia De Gerard De Nerval]. Bulletin de Méthodologie Sociologique, 26(1), 24-54. doi: $10.1177 / 075910639002600103$

Silva, C. C. B., \& Ramos, L. Z. (2014). Reações dos familiares frente à descoberta da deficiência dos filhos [Reactions of two family members to the discovery of their children's disability]. Cadernos de Terapia Ocupacional da UFSCar, 22(1), 15-23. doi:10.4322/cto.2014.003

Syed, I. H., Awan, W. A., \& Syeda, U. B. (2020). Caregiver burden among parents of hearing impaired and intellectually disabled children in Pakistan. Iranian Journal of Public Health, 49(2), 249-256. Retrieved from https://www.ncbi. nlm.nih.gov/pmc/articles/PMC7231703/

United Nations Convention on the Rights of the Child. (2015). Concluding observations on the combined second to fourth periodic reports of Brazil. Retrieved from http://tbinternet.ohchr.org/_layouts/treatybodyexternal/ Download.aspx? symbolno=CRC\%2FC\%2FBRA $\% 2 \mathrm{FCO} \% 2 \mathrm{~F} 2-4 \&$ Lang=en

Yin, R. K. (2004). Estudo de caso: Planejamento e métodos [Case study: Planning and methods] (D. Grassi, Trans.). Porto Alegre, RS: Bookman.

Zornig, S. M. A.-J. (2010). Tornar-se pai, tornar-se mãe: $\mathrm{O}$ processo de construção da parentalidade [Becoming a father, becoming a mother: The process of building parenting]. TempoPsicanalítico, 42(2),453-470. Retrieved from http://pepsic.bvsalud.org/scielo.php?script=sci arttext\&pid $=$ S0101-48382010000200010 
Julia Sursis Nobre Ferro Bucher-Maluschke is a Professor of the Centro Universitário de Brasília, Brasília-DF, Brazil.

Rosilda Alves de Oliveira, is a public servant at the Education Prosecutor's Office of the Public Ministry of the Federal District and Territories, Brazil.

Jonas Carvalho e Silva is an assistant Professor at the Technische Universität Dortmund, Germany.

Carlos Manoel Lopes Rodrigues is a Professor of the Centro Universitário de Brasília, Brasília-DF, Brazil.

Authors' Contribution:

All authors made substantial contributions to the conception and design of this study, to data analysis and interpretation, and to the manuscript revision and approval of the final version. All authors assume public responsibility for the content of the manuscript.

Associate Editor:

Wanderlei Abadio de Oliveira

Received: Jun. 29, 2020

1st Revision: Oct. 01, 2020

2nd Revision: Jan. 11, 2021

Approved: Mar. 20, 2021

How to cite this article:

Bucher-Maluschke, J. S. N. F., Oliveira, R., Silva, J. C., \& Rodrigues, C. M. L. (2021). Transformations in the family system after the birth of a child with disability. Paidéia (Ribeirão Preto), 31, e3124. doi:https://doi.org/10.1590/1982-4327e3124 